\title{
Muslim Ceutíes, Migrants, And Porteadores: Race, Security, and Tolerance at the Spanish-Moroccan BORDER $^{1}$
}

\author{
David Moffette
}

\begin{abstract}
This article analyzes the differential problematizations of "Muslim Ceutíes," "migrants," and "porteadores" (carriers) in the Spanish border town of Ceuta located on the south shore of the Gibraltar Strait in North Africa. I argue that convivencia, a local discourse and practice of tolerance meaning "living together," can be analyzed as a regime for governing differences premised on tolerance, and nevertheless contributing to the reproduction of a racialized and unequal social order. I also discuss the securitization of the border and argue against considering desecuritization and depoliticization as antidotes to securitization. I suggest that these strategies are complementary components of a flexible regime for managing the supposed threat posed by migrants in Ceuta. I further substantiate the thesis of a flexible regime for governing risks at the border by showing how various border crossers are framed and governed in Ceuta.
\end{abstract}

Keywords: Ceuta; convivencia; European border; race; securitization; tolerance.

Résumé. Cet article analyse la problématisation différenciée des "Ceutíes musulmans", "migrants" et "porteadores" (porteuses) dans l'enclave espagnole de Ceuta, située en Afrique du nord. J'y soutiens que la convivencia, un discours et une pratique de tolérance qui signifie "vivre-ensemble", peut être analysée en tant que régime de gouvernement des différences basé sur la tolérance et contribuant néanmoins à la reproduction d'un ordre social racialisé. Je traite aussi de la sécurisation de la frontière et soutiens que la dé-sécurisation et la dépolitisation ne doivent pas être considérées comme des antidotes à la sécurisation, mais plutôt que comme des éléments complémentaires d'un régime flexible de gestion des menaces présumées. Je développe cette thèse d'un régime flexible de gouvernement des risques à la frontière en exposant comment le passage de différents types de personnes à travers la frontière est problématisé à Ceuta.

Mots clés: Ceuta; convivencia; frontière européenne; race; sécurisation; tolérance.

1. Acknowledgement: I would like to thank the anonymous reviewers as well as the guest editors of this issue for their insightful comments. This article has won the CanadaMediterranean Centre's 2013 "Hédi Bouraoui Mediterranean Studies Award." 
mpirical research at borderlands often produces complex and contradictory findings. When looking for hybridization, one often finds reified identities, yet when looking for militarization, one often finds a rather porous border. The Spanish border town of Ceuta, located on the southern shore of the Gibraltar Strait in North Africa, is no exception. In this $18 \mathrm{~km}^{2}$ enclave city situated at the border of Morocco and the European Union, one witnesses at once racism and tolerance, securitization and desecuritization, and a fortress-like and yet porous border. I say "at once" to suggest that these are not distinct and opposite phenomena. Rather, they are complementary dimensions of the local regime for governing difference at the border.

Using data previously collected for research on the securitization of immigration in Ceuta and based on a discourse analysis of more than 200 opinion pieces published in a local daily paper between 1985-2007 (editorials, columns, op-eds, and letters to the editor), as well as on participant observation and semistructured interviews conducted in 2007, this paper focuses on the differential problematizations of three racialized categories of people circulating among the so-called "Christian majority" in Ceuta: "Muslim Ceutíes," "migrants," and "porteadores." Through a critical analysis of the "Christian" majority's framing and governing of these three categories of individuals, my first objective is to question Ceuta's version of multiculturalism, organized around the concept of convivencia, in order to go beyond its usual depiction as either an ideal of tolerance or a mask for a racist order. While providing empirical descriptions of Ceuta's race relations, I will argue that convivencia is premised on both racism and tolerance. The first section, titled Convivencia: Pacifying Muslim Ceuties, will thus engage with both overt racism and tolerance in the management of difference in Ceuta. Even as it prevents blatant racism by promoting tolerance, Ceuta's convivencia is intimately tied to race, as "a way (or a set of ways) of being in the world, of living, of meaning-making" (Goldberg 2009:152). Accordingly, one of the main arguments of this paper is that convivencia should be considered a regime for governing differences premised on tolerance and nonetheless contributing to the reproduction of an unequal and racialized social order.

My second related objective is to address the apparent contradictions arising from the coexistence of the projects of strengthening border control, on the one hand, and facilitating irregular border crossings on the other. Consequently, the second section titled Flexible Securitization: Filtering Border Crossers will discuss the related governing of two types of border crossers: "migrants" and "porteadores," or carriers. This section will discuss the discursive and material dimensions of the securitization process, and explain the role it plays in the preservation and reproduction of this pacified social order that is convivencia. I also question the opposition of securitization and desecuritization present in the literature in critical security studies and suggest that, in this context, these two strategies work together to facilitate a flexible management of difference at the border. I will argue that border controls and securitization of immigration, far from leading to the construction of an actual Fortress Europe, are instead tools mobilized to filter types of circulation, "optimize" populations, and reproduce an unequal social order. While the analysis centres on Ceuta, the paper also makes theoretical contributions to the scholarship that explores the intersections between multiculturalism, securitization, racism, and liberal government.

\section{Map of Ceuta}

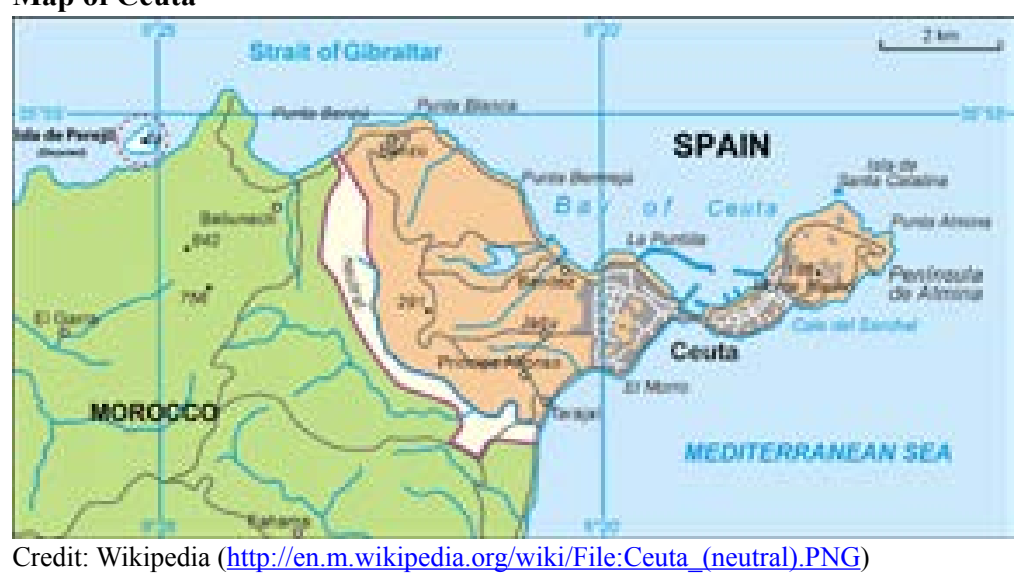

The Problematizations of Racialized Categories of Individuals

Adapting Foucault $(1985 ; 2004)$, I take problematizations to be the result of historically situated discursive and nondiscursive practices that provide specific ways of thinking about and acting upon objects. In this sense, the problematizations of "Muslim Ceutíes," "migrants," and "porteadores" that circulate among the "Christian majority" are not simply the discursive framings of groups of people, but their inscription, as objects of knowledge and government, into grids of intelligibility (Bacchi 2012). They partake in racial projects by connecting

what race [but also religion, gender, class, and legal immigration status] means in a particular discursive practice and the ways in which both social structures and everyday experiences are racially organized. (Omi and Winant 1994:56; italics in original)

Therefore, even as I focus only on problematizations that circulate among Christian Ceutíes (and thus pay little attention to the perspec- 
tives of other communities), the problematizations and the categories they mobilize have to be understood as "multiply determined, politically contested, and deeply shared by their historical [and geographical] context" (Omi and Winant 1994:57).

The importance that many Christian Ceutíes I interviewed granted to the classification of individuals into the "proper" categories led me to interrogate the differential problematizations of these categories of people. In fact, the organization of identity in the city relies heavily on a division into "communities." Indeed, the population of Ceuta is generally accounted for in terms of religious communities and divided into Christians or Spaniards (42,000 individuals, $58 \%$ of the population), Muslims (27,000 individuals, $38 \%$ of the population), Jews (2000 individuals, $3 \%$ of the population), and Hindus (500 individuals, $1 \%$ of the population) (Irujo 2005). These categories do not necessarily refer to religious beliefs, however. Rather they are putatively and/or self-attributed identities based on name, country of origin, physical traits, social position, or religion, and are often defined in everyday conversations by an amalgam of religious practices, popular culture, and values. They are thus fluid, messy, and contested categories resulting from the "racing of religion" (Bayoumi 2006), a central feature of the history of Spanish racism (Mariscal 1998; Frederickson 2003). My use of the terms reflects their use in Ceuta.

\section{Convivencia: Pacifying Muslim Ceutíes}

When asking Christian Ceutíes about racism in Ceuta, the first answer is almost invariably: "No, Ceuta is not racist! You know there is good convivencia here... Ceuta is the result of the meeting of four cultures." But, as one might expect, the reality is not so pretty. In a sense, referring to convivencia as proof that there is no racism in Ceuta is tantamount to invoking multiculturalism to claim that Canada is free of racism. For this reason, the concept of convivencia will be put in relation with analyses of multiculturalism as a regime for governing differences (Brown 2006; Kernerman 2005) and as ideology (Bannerji 2000). The contemporary use of the notion of convivencia also reactivates certain myths of tolerance and race that are inscribed in historical narratives about Spanish identity and that should be discussed in their own right (Goode 2009; Soifer 2009). Before engaging with these questions, however, it is useful to give an overview of the empirical convivencia, or living-together, in Ceuta.

\section{A Segregated City}

The official website of the City of Ceuta describes it as "a city open to the world" characterized by the cultures and idiosyncrasies of Christian, Muslims, Hindus, and Jews .. mixing, and forming the main communities of this cosmopolitan population whose markers of identity are respect and convivencia. (Ceuta Digital 2005:n.p.)

And yet, the reality is not so idyllic. Ceuta is geographically segregated along racial-religious lines. Muslims live mainly in the impoverished neighbourhoods of El Principe Alfonso and Benzú near the border with Morocco, and Rosales and Jadú closer to the centre but still considered "noncentral" by the President of the Autonomous City (Irujo 2005). Christians occupy the downtown area, whose streets are regularly repaved and decorated by statues commissioned from local artists.

As González Enriquez (2007:223) has pointed out, in addition to this urban segregation, the very limited intercommunal integration also appears quite clearly in "the small number of mixed marriages, the lack of common festivals ... and the tendency of parents of Spanish origin to avoid schools with high percentages of Muslim children." With regards to mixed marriages, González Enriquez cites as an example the year 2003 during which, according to her estimations, there were only 28 marriages between Muslims and non-Muslims out of a total of 243, thus representing only $11.5 \%$ of all marriages.

The city is also segregated at the level of everyday interactions. There are plenty of cordial and respectful interactions between individuals for business in the centre during the day and many Muslims own or work in stores, cafes, and stands in the central market. Many bonds of friendship also exist between Christian and Muslim individuals. Yet, the two communities maintain social boundaries and at night, most Muslims leave the centre to go back to Muslim neighbourhoods, while many Christians interviewed consider these neighbourhoods to be dangerous. In his dissertation on local politics in Ceuta, Torres Colón (2008) describes five types of intercommunity relations: friendly, neutral, evasive, confrontational, and violent, with neutral and evasive being the most prevalent forms. Evasive responses to everyday conflicts leave most of them unresolved and there are constant latent tensions in the enclave.

While evasive responses and prudent tolerance are the most common means for containing tensions in Ceuta, violent and overtly racist incidents are also frequent. A rather extreme example is the infamous case of the racist play that won the 2006 carnival competition. During this Christian festivity, local groups perform chirigotas, short satirical musical pieces that are performed on stage in front of a large public. In 2006, the municipal authorities granted the prize for the best chirigota to a group who performed an overtly racist piece, outraging the Muslim 
community and many non-Muslim Ceutíes. The lyrics, written by a local police officer and performed by twelve individuals in front of a large crowd, included the following lines:

When I grow up I wanna be a veterinarian.

Here there are enough sheep to make a living.

What a flock, what a flock!

We'll stop using condoms

Since the two populations we're already equal [in numbers].

So I went directly to the book of natural sciences

To look up if the Turks [an obvious reference to Muslims]

Are rational animals.

I saw that these people and bovines are the same.

It confirmed my suspicion:

They are all animals.

Before I go: What a bad job Hitler did

Here I am showing face and unarmed.

I prefer dying on my feet than living on my knees.

The fact that the municipal government sanctioned this chirigota as the best of the carnival demonstrates that such blatant racism is common enough for the local authorities not to consider it problematic. Considering that a similar scandal had occurred the previous year when a chirigota compared Muslims to gorillas that cannot adapt to the Western way of life, are a danger to Christian children, and whose sole utility is to clean the houses of Christian Ceutíes, it was surprising to see the President of the Autonomous City of Ceuta insist that he did not consider the lyrics racist, and argue for a week that the prize should be maintained before finally giving in to pressures and rescinding the prize. After all, these cases of overt racism mobilize the biological and historical references that characterize the most blatant racism generally condemned throughout Europe (Goode 2009; Goldberg 2009).

Cases such as these as well as the everyday frictions between the two major communities clearly indicate that convivencia, in its ideal version, is not an empirical reality. But does it mean that convivencia is nothing more than a fraud, a touristic slogan used by the authorities to attract visitors or cover the racism and violence occurring at this European border? Responding in the affirmative would amount to reproducing the binary opposition of convivencia as harmony on the one hand, and racist conflicts on the other. So would a position analyzing convivencia as an ideal of harmonious living that is unfortunately not yet fully achieved. In fact, even as it prevents blatant outbursts of racism by promoting tolerance, Ceuta's convivencia is intimately tied to race. Accordingly, I contend that convivencia should be considered a regime for governing differences premised on tolerance, and reproducing a pacified and racialized social order that contributes to subject formation and to the securing of Ceuta's identity as a Spanish city.

\section{Convivencia, Race, and Españolidad}

A genealogy of the concept of convivencia in narratives of Spanish identity sheds light on some of its contemporary articulations in Ceuta. The concept of convivencia was first used in 1948 by Spanish historian Américo Castro to account for relations among Christians, Muslims, and Jews in medieval Iberia, arguing that the origin of Spanishness is to be found in this moment of intercultural mestizaje. In the famous academic debate that pitted him against Claudio Sánchez-Albornoz, Castro's historical narrative was a powerful challenge to the version of Spanish history that constructs Spanish identity as a direct Roman heritage. As Soifer (2009) explains, this conservative perspective argues that "Castile, uncontaminated by the Islamic invasion and by centuries of interaction with the Jews, led Spain through the centuries-long Reconquista toward the fulfillment of its manifest destiny of 'reunification." In this context, by "postulating the existence of a cultural symbiosis in medieval Iberia, convivencia problematized the pristine image of homo hispanus and provided a much-needed corrective to the mythological construct of 'eternal Spain" (Soifer 2009:20; italics in the original). Yet, while convivencia emerged as part of a necessary counter-narrative, it has been broadly mobilized in a redemptive fashion in the post World War II context and has contributed to an academic fascination with purportedly medieval Spanish tolerance and what Soifer (2009:24) calls "the nationalist myth of Spain's unique status in medieval Europe," an argument famously made by Glick (1979). A review of the debates among historians about tolerance and convivencia in medieval Iberia is beyond the scope of this paper. What is important to note here is the way this concept of convivencia is central to the now dominant popular notion of Spanishness that presents Spain as an exceptional case of tolerance and mestizaje in Europe.

As this notion of mestizaje suggests, the nationalist myth of Spanish exceptional tolerance is also important with regard to race. In his study of notions of race in Spain from the late 18th to the early 20th centuries, Goode (2009) argues that Spanish racial thought is based on a celebration of racial hybridity that informs Spanish nationalism. Goode's work is in part an attempt at analyzing a modern notion of race that is not based on racial purity but on this idea of hybridity or fusion, and to 
underscore that the content of the notion of race is less important than its role as a mode of thought. Drawing on the work of Frederickson (2003), Goode (2009:14) suggests that:

One might say that the Spanish version [of the notion of race], the idea of fusion, is a racism of inclusion, "incorporating groups on the basis of a rigid hierarchy justified by a belief in permanent, unbridgeable differences between associated groups." Yet, Spanish notions of race prove that a simple bifurcation of inclusive or exclusive racial thought is unnecessary. Modern Spanish racial thought rooted in fusion was in a sense inclusive, while the purposes to which it was put always led to [a] divisive sense of ethnic isolation. There is nothing benign or surprising in the Spanish notion of fusion or its social use or deployment. Inclusive racism does not preempt the creation of crude racist practices.

Goode's claim that the Spanish modern notion of race was based on hybridity tends to obliterate the fact that the fascination for racial purity has existed alongside notions of mestizaje in Spain since at least early modern times (Mariscal 1998; Vázquez García 2009), and that a robust strain of Spanish historiography continues to emphasize Castilian purity today, long after the debate between Sánchez-Albornoz and Castro (Soifer 2009). Nevertheless, his analysis of a particular form of racial thought that is both inclusive and hierarchical, that incorporates groups and maintains and organizes differences, and that is central to Spanish nationalism is insightful. While being careful not to transpose Goode's argument about Spanish modern notions of race or Castro's concept of medieval convivencia directly onto the contemporary situation of Ceuta, understanding the central role that notions of tolerance, convivencia, and inclusion played in the construction of the historical narratives of Spanishness is essential for analyzing the way convivencia works in Ceuta.

Geographically and politically distant from the Spanish capital and separated from the European continent by some $14 \mathrm{~km}$ of water, Christian Ceutíes passionately defend the españolidad, or Spanishness of the city. Generally, statements that Ceuta is strongly influenced by Moroccan culture, and claims that the city is stolen land belonging to Morocco, provoke strong reactions in Ceuta. Most such claims are answered by local journalists and politicians defending the "historically founded" Spanishness of their city and pressuring the central government in Madrid to reaffirm its policy of never ceding Ceuta to the neighbouring state. This recurrent reference to the Spanishness of Ceuta, while denying Moroccan influence for geopolitical reasons, is nevertheless presented as inclusive of the Muslim community. Indeed, the notion of españolidad is generally mobilized by Christian Ceutíes as encompassing the cultural contributions of the Christian, Muslim, Jewish, and Hindu communities gathered together in this unique convivencia. In this regard, convivencia is framed as Spanish in its essence, as a project possible only within a Spanish context, and essential to the future of Ceuta's allegiance to the Spanish state. In the context of the demographic expansion of the Muslim community, and its growing influence on local politics, convivencia is mobilized as a symbol of collective Spanish identity in an attempt to secure Muslims' allegiance to Spain and commitment to the pacified order of things.

\section{Muslims' Political Demands and Christians' Fears}

The prevalence of the contemporary discourse of convivencia in defining Ceuta's identity appears in the context of the demographic growth of the Muslim community and its pressing political demands for recognition and economic justice, especially in the last decade. According to the only census which included questions on religion conducted in 1986, there were around 15,000 Muslims living in Ceuta (around 21\% of the population) with only 2,400 of them having Spanish nationality (Gold 2000). In 2005, the national daily paper El País caused a small panic among Christian Ceutíes by revealing numbers supposedly leaked from a classified report of the Spanish armed forces titled "Vulnerabilities and Threats," suggesting that Muslims represented 38\% of Ceuta's population and would form the majority by 2018 (Irujo 2005).

One could reasonably ask why, if the identity of the city is based on the convivencia of the four cultures, the demographic proportions of these cultures are so essential. After all, the current trend is toward a more proportionate representation of the two main communities. Yet, as we have seen, españolidad and convivencia are mutually constitutive in this discourse, and while the Muslim community is framed as an essential part of this order, the Christian community must remain dominant. In this sense, González Enríquez (2007:225) is right to claim that, " $[t]$ he fear of the population of Spanish origin to become a minority in a short period of time has two different implications: the first is their apprehension regarding an eventual islamisation of social life, and the second, more explicit, is the fear of a reversal of sovereignty" that would see a Muslim majority mobilize to have the town annexed by Morocco. While these fears are commonly held, they appear unfounded. Even if one of the so-called local "Muslim parties" came to control the local government, these scenarios are not likely to occur. Indeed, as an elected candidate of the influential Unión Democrática Ceutí (UDCE) told me, the UDCE is not a "Muslim party," let alone an Islamist or a 
secessionist party. Rather, it is simply a party formed by Muslims to address problems disproportionately affecting the Muslim community such as poverty, low levels of academic success, poor living conditions, or lack of infrastructure. Rather than being grounded in evidence, these fears appear to be informed by a modality of race thinking that unfolds globally with regardD to Muslims and that is "underpinned by the idea that modern enlightened, secular peoples must protect themselves from pre-modern, religious peoples whose loyalty to tribe and community reigns over their commitment to the rule of law" (Razack 2008:9-10).

A third, and more likely, potential consequence of the growth of the Muslim community is the weakening of the Christian political, economic, and cultural hegemony. Since the mid-1980s, Muslim Ceutíes have defended their political rights, formed political parties and organizations, denounced racism and islamophobia, demanded affirmative action policies, recognition of their language in schools, and better living conditions. While the demands for rights can be seen as a minority's quest for recognition, I would suggest that at this EU-Moroccan border that has long been considered the frontier of a civilizing effort, it is useful to think of this process as the decolonization process reaching the metropole. Indeed, while Ceuta has belonged to Spain since 1668, long before the Spanish colonial administration in the region (1913-1956) and is thus not generally considered a colonial town, it has played a central role in Spain's colonial project. In this context, the attitudes and positions of many Christian Ceutíes today bear uncanny similarities to Memmi's (1985) depiction of the various attitudes of the figure of the colonizer, including resentment against the metropole, patriotism, selfdeprecation, temptation of fascism, and fear of low-rank settlers of losing privileges. While I do not contend that there is a project to decolonize the enclave's territory, and not even that many Muslim Ceutíes consider it a colonized territory, I suggest it is useful to consider the Muslims' political demands as a process aiming at decolonizing social relations. In fact, many Ceutíes recognize that the biggest threat posed by the growth of the Muslim community is a threat to privileges and social relations inherited from the colonial period.

Although this concern about privilege is rarely expressed publicly, it was articulated in various interviews I conducted with Christian Ceutíes. In one interview, a public servant who was born in Tangiers during the Protectorate, had moved to Ceuta with her parents after Moroccan independence in 1965, and has worked for various local administrations over the last 20 years, gave voice to this concern:

But the fault is not only ours, I mean the Europeans. Muslims are very racist people too. They want, and I find this normal,... more rights as time passes. Because 15-20 years ago, the Muslims who were here were people who went to the market to sell goods, poor people, without education. Then the families developed and the children went to school, and with education comes demands: "What? My father doesn't have water in his house? That can't be!" ... Of course, everyone has the right to evolve for the better.

The elders kept quiet.... In the new generations, a lot of people go to university, and I think it's good. And knowledge gives you the power to demand more for your life. Before, you had your eyes shut. Now, you discover the world and the government provides help.... And so, people improve their conditions. But this improvement brings about further demands. And what happens? The Spaniard of Ceuta would prefer that the Muslim who lives here didn't ask for anything. But the Muslim produces a lot of kids. And therefore Ceuta is increasing much more on the Muslim side than on the Christian side.... And [their children], as time goes by ... will be allowed to vote. And the people don't want that. They think that maybe one day the City government will have a Muslim mayor....

So the Spaniard has this concern that he doesn't express. But he thinks: time goes by and every four years there are more people voting in the elections and, well.... If there are classrooms where you have 40 Muslim kids and only one Christian kid nowadays.... And what does that mean? Well, that the people are concerned.... There are already Muslim representatives in the local government....

This interview excerpt shows the tension between a moral position that supports the recognition of rights and a calculative position to protect the Christian majority's economic, political, and cultural privileges. It is as if this civil servant understood that when there are historically established systemic inequalities, an oppressed group's quest for equality is a direct threat to a dominant group's hegemony. In this context, the discourse of convivencia is also a means of alleviating tensions in a town where politicized differences appear as a threat to the pacified order of things, an order that is seen as securing Spanishness, and its privileges.

\section{Pacifying Muslim Ceutíes}

In previous works on the securitization of transit migration in Ceuta (Moffette 2010), I have focused on convivencia as a local pacified order of things, following Malkki's (1995) concept of the national order of things and its more recent rearticulation by Haddad (2007). Avoiding the structuralist dimension that Malkki's concept implies, Torres Colón (2008:182) has considered convivencia as an ordering concept, a sort of cognitive map of social relations that Ceutíes mobilize to navigate the social space and through which "they bring a certain order to their every- 
day experiences as musulmanes and cristianos." Considered together, these two perspectives point to convivencia as a regime for governing differences that produces and transforms in a dynamic fashion the pacified order of things as well as political subjectivities. Following Omi and Winant (1994:56), we can therefore consider convivencia as a racial project that contributes to the process of racial formation in Ceuta since it "is simultaneously an interpretation, representation, or explanation of racial dynamics, and an effort to reorganize and redistribute resources along particular racial lines." Like other racial projects, convivencia "connect[s] what race means in a particular discursive practice and the ways in which both social structures and everyday experiences are racially organized, based upon that meaning" (Omi and Winant 1994:56; italics in the original). It is, for Christian Ceutíes, a means of emphasizing racial differences in a way that integrates them into the national context and helps structure the narrative of Ceuta's Spanishness. It is the process through which fears, tensions, and dreams regarding the enclave's identity and future are constantly ordered in a precarious equilibrium. Confronted with the demographic growth and political influence of the Muslim community, Christian Ceutíes often portray convivencia as the only way to defend the Spanishness of the city. In other words, the discourse of convivencia is also a precarious attempt to pacify differences and sustain the cultural, political, and economic domination of the Christian community.

Convivencia thus plays a role in pacifying Muslim Ceutíes, and in that sense it presents similarities with the Canadian official multiculturalist discourse whose role as a means of "civilizing differences" (Kerneman 2005:11) or as an ideology (Bannerji 2000) has been the object of critical scrutiny. While there are also differences between the AngloSaxon concepts of multiculturalism and the Spanish concept of convivencia (Torres Colón 2008), critiques of multiculturalism are germane to the study of convivencia. For instance, Bannerji (2000:6) argues that considering the official multiculturalist discourse as an ideology can help us in understanding its work "as a device for constructing and ascribing political subjectivities and agencies for those who are seen as legitimate and full citizens and others who are peripheral to this in many senses." She suggests that the dissatisfactions and political demands that emerge from migrants" "raced and gendered class existence" force authorities to call "for the creation of an ideology and apparatus of multiculturalism (with its discourse of a specific kind of plurality called diversity) as a strategy of containment and management" (Bannerji 2000:34, 43). While I do not mobilize the concept of ideology, I contend that this approach offers useful insights to analyze the (de)politicizing role of con- vivencia. As we have seen in this section, convivencia, like multiculturalism, actively constructs the notion of Spanish and local tolerance, contributes to the classification of individuals into racialized categories, constructs racialized political subjectivities, orients actions, and helps contain tensions by culturalizing (and thus depoliticizing) political demands. In short, as in other political regimes based on the notion of tolerance, the depoliticizing dimension of convivencia "involves construing inequality, subordination, marginalization, and social conflict, which all require political analysis and political solutions,... as natural, religious, or cultural" (Brown 2006:15).

\section{Flexible Securitization: Filtering Border Crossers}

The representation of convivencia as a pacified and tolerant order is complemented by the governing of border crossers as potential threats. Indeed, convivencia is framed by many Christian Ceutíes as a precarious equilibrium, threatened internally by the growth of the Muslim population, and externally by the problems associated with the border. The securitization of some border crossers is thus closely related to the moral panic about the future of convivencia, while the governing of Muslim Ceutíes through practices and discourses of convivencia finds legitimization in the threats associated with Ceuta's location at the border. For this reason, an analysis of the governing of differences at this border needs to consider the attempts to pacify Muslim Ceutíes alongside the flexible securitization of border crossers such as migrants and porteadores.

Unauthorized Migrants: Between Securitization and Depoliticization

Of all border crossers, Algerian and sub-Saharan African migrants using Ceuta as an entry point into the European Union, and poor Moroccan youth trying to make a living in the city, are the most commonly framed as a threat and a problem of security. When successful, these claims lead to the securitization of immigration, a process whereby migration is framed as an existential threat legitimizing exceptional means (Buzan et al. 1998). In fact, the issue of transit migration is particularly salient at this border and attempts at securitizing the issue are common. This is not surprising since both Ceuta and its sister enclave city Melilla located further east on the northern shore of Morocco are European cities in the African continent. For this reason, they attract African and Asian migrants transiting through Morocco to reach the European Union. Those who travel through Ceuta generally do so in precarious conditions, often crossing the border without authorization after a long and difficult journey through the desert. For them, entering Ceuta and 
Melilla means entering the European Union. Nevertheless, when Spain ratified the Schengen Agreement in 1991, a special status was given to Ceuta and Melilla allowing Moroccans from the neighbouring provinces of Tetouan and Nador to enter the enclaves without having to produce a Schengen visa. This was done to facilitate economic activities in the region. In exchange for this exception, however, immigration control occurs at the ferries linking the North African Spanish towns to mainland Spain. As a result, irregular migrants and asylum seekers who succeed in entering Ceuta and Melilla are unable to go further and stay in the small enclaves for long periods of time before being either deported or transferred to mainland Spain.

This context has led to regular attempts to frame unauthorized migration as a threat in Ceuta. This is especially the case when these migrants share physical characteristics with some Ceutíes. For example, when Algerian migrants or unaccompanied Moroccan minors stay in the city for some time, some Ceutíes express concerns about the possibility that these migrants might be confused with Muslim Ceutíes, and that any crime or misbehaviour they might commit would be attributed to the Muslim community of Ceuta. Such confusion over the "proper" categorization of individuals into the racialized groups they are assumed to represent creates anxiety and is considered a potential threat to good convivencia. Letters published in local newspapers in 2000, when parents of students were trying to impede the schooling of unaccompanied Moroccan children at Juan Morejón College, reveal this preoccupation. Since these children come from poor and marginalized neighbourhoods of nearby Moroccan towns and are in Ceuta irregularly, they are presented as potentially dangerous. In a letter entitled "We are not equal," a man deplored the decision to school Moroccan minors. He wrote:

Here, there are 25.000 Muslims waiting for their rights and for enhancements on social issues before those from outside, who can spatter their kids in our schools. If some quarrel or vandalism occurs, those who do not distinguish between Spanish Muslims with their rights [and others], will accuse them all the same as those from outside because the orders of Madrid ... do not take into account that we are not all equal.... And if Ceuta keeps like this, it may well break into pieces if we don't solve the problem of the illegals at the border.

Apart from portraying migrants as a threat to the order of things, securitizing discourses also regularly depict migrants as potential delinquents, criminals, sexual predators, or vectors of disease that pose a physical threat to Ceutíes. Even the Moroccan children at the Juan Morejón College were framed in another letter to the editor as "thirty delinquents who would have no remorse to use a knife to steal a sandwich," and as "thirty potential rapists." The term "potential" is important here. Sub-Saharan African and Asian irregular migrants transiting through Ceuta are also often framed as being potentially contaminated by violence. For instance, in one interview, a man tried to make sense of a riot started by migrants in 1995 by saying: "It's not their fault, but they come from war-torn countries, and they carry with them this reality even if they stay peaceful most of the time." While these discourses do not generally portray irregular migrants as inherently violent or dangerous, they frame them as more risky than others from the mere fact of having known war, used illegal means to cross borders, or being poor. In this type of problematization, threats

can be anticipated but never known for certain; the contagious body that passes by ... infects other bodies, [and this] stickiness can draw into question almost anyone in this affective economy of fear: pools of bodies, populations. (Puar 2007:195)

Racialized bodies are thus read and framed as potential threats based on an assessment of putative past experiences, origin, class, gender, type of border crossing, and citizenship status.

Such attempts to frame unauthorized migration and migrants as a threat have led to successful occurrences of securitization. These generally include a call for expelling transiting migrants, either by deporting them or by having them transferred to mainland Spain as soon as possible. They have also directly contributed to the erection of a border apparatus organized around a double barbwire-covered fence that ranges from 3 to 6.2 meters in height and is supplemented by radars, infrared cameras, surveillance towers, and a patrol road. I have analyzed these processes of securitization in detail elsewhere (Moffette 2010) and will not reproduce the analysis here. Instead, I want to highlight how both strategies of securitization and desecuritization (but also depoliticization) are mobilized simultaneously to manage the figure of the irregular migrant at the border.

Indeed, considering the local situation as a "real powder keg" (Cózar 2005:3), Christian Ceutíes avoid playing with fire and, as in the case of intercommunal tensions, try to depoliticize the issue. This strategy was summarized to me by a man who told me that he sees Ceuta as a boat isolated on the ocean with a time bomb on it: everyone has to work together to defuse it. The worst thing to do would be to politicize the problem. "When there is such a precarious yet dangerous situation, you do like policemen do when there is an accident, you say: 'Keep going! Everything is fine! There is no problem!'" he explained. The depoliticiz- 
ing strategy is thus generally favoured by Ceutíes but the two strategies coexist and often complement each other.

This situation suggests that, instead of considering securitization and desecuritization as two diametrically opposed concepts, with desecuritization as the preferred pacifist solution (which is often the case in critical security studies), it would be more productive to consider both strategies as complementary approaches within a broader regime of governmentality organized around tolerance and unease. Indeed, tolerance, desecuritization, and depoliticization cannot simply be considered the antidote to securitization as Buzan et al. (1998) would have it. As Brown (2006:27) explains, the

very invocation of tolerance ... indicates that something contaminating or dangerous is at hand, or something foreign is at issue, and the limits of tolerance are determined by how much of this toxicity can be accommodated without destroying the object, value, claim, or body.

Discourses and practices of tolerance are themselves a privilege of the majority, the power to decide on the extent and limits of tolerance (Hage 2000). Tolerance, intolerance, depoliticization, and securitization should therefore be analyzed as part of a flexible regime of government that works through the management of unease (Bigo 2002) and mobilizes techniques ranging from tolerance to state violence in order to govern risks at the border.

\section{Porteadores: Facilitating Transborder Trade}

This interpretation of securitization as part of a broader regime aiming at managing risks according to logics of optimization (Huysmans 2006) is also useful for addressing the differential treatment that unauthorized migrants and porteadores receive at the border. Indeed, the securitization of unauthorized migration as well as the material response in the strengthening of the border dispositif contrasts with the treatment extended to the porteadores whose circulation across the border is deemed necessary and is somewhat facilitated (although under very precarious conditions).

As Berg and Ehin (2006:65) explain, with the special clauses of the Schengen agreements allowing Moroccans from the provinces surrounding Ceuta and Melilla to enter the cities without a visa, the Spanish enclaves are a good example of "pretended exclusiveness":

On the one hand, Spain contributes to the construction of Fortress Europe ... while on the other hand it cannot ignore local pressures to open up the enclaves for more intensive interaction with the surrounding areas.
In fact, the smuggling of goods across the border as well as transborder work are a key component of the economy of the Moroccan border region, while the cheap labour source that Moroccan workers represent is essential to Ceuta's economic prosperity (López Sala 2012). For this reason, every time a police union or political party calls for strengthening border control, other political parties and the business sector defend the need for facilitating transborder trade. This tension between commercial and security interests is common at most borders around the world, but what sets Ceuta apart is that since the town is not recognized by Morocco, there is no customs at the Ceuta-Moroccan border. For this reason, the trade across the border takes the form of "contraband," according to Moroccan authorities, an activity that is dubbed "irregular or atypical" in Ceuta (Ferrer Gallardo 2008). This business sector moves somewhere between $€ 500$ and $€ 700$ million per year (Quesada 2010) and in so doing, generates around $70 \%$ of Ceuta's wealth according to estimates of the local business association published in 2003 (Abad 2003). For contraband to happen at this magnitude, infrastructure has been put in place by Spain and Morocco to facilitate it.

Since they do not need a Schengen visa to enter the town, about 30,000 Moroccans from the nearby region cross the border daily to work or buy goods. While some of the workers are granted transborder work permits that allow them to work legally in Ceuta without allowing them to live in the city, many are employed without a permit in the extensive underground economy. Poorly paid and with little access to rights and protections, these daily transborder workers have been used as a source of cheap labour in the construction and domestic sectors for years now. In fact, López Sala (2012) suggests that most transborder workers are women working in the domestic sector, explaining that in 2008, more than $50 \%$ of the transborder work permits were granted for domestic workers.

Of the 30,000 Moroccans who cross the border daily, 8,000-15,000 of them, mostly older divorced or widowed women (López Sala 2012), do it as porteadores (carriers). If workers with transborder work permits have very few rights, and workers without working permits have even less, porteadores work in the most precarious conditions. From Monday to Thursday, they cross the Tarajal border point into Ceuta early in the morning to go to a commercial storage facility near the border. Once there, they fill bags with between $50-70 \mathrm{~kg}$ of everyday products and cross them on their backs into Morocco through a fenced corridor that was opened in 2005 to facilitate the sanctioned smuggling of goods across the border. These Moroccan women can cross about four times before the fenced corridor, called the Buitz bridge, closes at $1 \mathrm{pm}$. They 
make between 10-50 dirhams (CAD\$ 1.15-5.80) per trip (Cembrero 2009; Abad 2003; personal communication with the Sindicato Unificado de Policía 2007).

The existence of the Biutz bridge reminds us of the contradictions of border securitization in the most obvious way. While several scholars have exposed the contradictory logics of immigration and border controls for a long time now (Calavita 1989; Kearney 1991), seeing thousands of people "smuggling" goods through a fenced corridor built by Spain and Morocco expressly to allow porteadores to circulate across the border with only minimal control makes for a surreal sight. This sanctioned "hole in the border" substantiates the claim that borders do not work as walls aiming at keeping outsiders out, but rather as filters through which various categories of individuals are authorized to move. As Huysmans (2006:100) explains, in this selective process " $[t]$ he central instrument is one of profiling those people within the population that are considered to have a higher predisposition towards suboptimal or dangerous conduct." In Ceuta, both unauthorized migrants and porteadores are profiled as risky individuals, but while porteadores are considered a necessary evil for Ceuta's business sector, the economic usefulness of unauthorized migrants is deemed low or nonexistent. For this reason, in the flexible regime for governing differences that is in place at this border, porteadores are most likely to be silently tolerated while the threshold of tolerance towards migrants is much lower, thus making them a more likely object of securitization.

\section{Conclusion: (In)Tolerance as a Flexible Mode of Government}

The analysis of the distinct framing and policing of the figures of "Muslim Ceutíes," "migrants," and "porteadores" has served to demonstrate that dichotomies such as tolerance/racism, securitization/desecuritization, inclusion/exclusion, or Fortress Europe/porous borders conceal more than they reveal about the flexible governing of difference in Ceuta.

With regard to convivencia, I have argued that it is neither an ideal model of tolerance, nor a fraud covering up racist behaviours. Instead, I have suggested that it is a regime for governing differences premised upon tolerance, and nevertheless contributing to the reproduction of a pacified and racialized social order. This interpretation of convivencia has also highlighted how the idea and practice of "cultural tolerance" is itself based upon a certain modality of race thinking. Regarding securitization, I have argued against considering desecuritization and depoliticization as antidotes to securitization and suggested that these strategies are complementary components of a flexible regime for managing the supposed threat posed by migrants in Ceuta. I have further substantiated this idea of a flexible regime for governing risks at the border by showing how various border crossers are framed and governed differently at this European border. Through these arguments, I have demonstrated how (in)tolerance works as the central premise of a flexible regime for governing differences and securing privileges in Ceuta, and thus contributed to the scholarship that explores the intersections between multiculturalism, securitization, racism, and liberal government.

\section{REFERENCES}

Abad, Rocío. 2003. Una ciudad que vive de la frontera. El País, October 5. http://elpais.com/diario/2003/10/05/espana/1065304805 850215.html. Accessed 26 May 2012.

Bacchi, Carol. 2012. Why study problematizations? Making politics visible. Open Journal of Political Science 2(1):1-8.

Bannerji, Himani. 2000. The Dark Side of the Nation: Essays on Multiculturalism, Nationalism and Gender. Toronto: Canadian Scholars' Press.

Bayoumi, Moustafa. 2006. Racing religion. The New Centennial Review $6(2): 267-293$.

Bigo, Didier. 2002. Security and immigration: Toward a critique of the governmentality of unease. Alternatives 27:63-92.

Berg, Eiki and Piret Ehin. 2006. What kind of border regime is in the making? Towards a differentiated and uneven border strategy. Cooperation and Conflict 41(1):53-71.

Brown, Wendy. 2006. Regulating Aversion: Tolerance in the Age of Identity and Empire. Princeton, NJ: Princeton University Press.

Buzan, Barry, Ole Wæver, and Jaap de Wilde. 1998. Security: A New Framework for Analysis. London: Lynne Rienner.

Calavita, Kitty. 1989. The contradictions of immigration lawmaking: The Immigration Reform and Control Act of 1986. Law \& Policy 11(1):17-47.

Cembrero, Ignacio. 2009. Una avalancha causa la muerte de dos porteadores en Ceuta. El País, May 26. http://elpais.com/diario/2009/05/26/ espana/1243288817 850215.html. Accessed 26 May 2012.

Ceuta Digital. 2005. Información general. Ceuta Digital: El portal oficial de la Ciudad Autónoma de Ceuta. www.ceuta.es/servlet/ ContentServer?idioma $=$ es es\&is $\mathrm{P}=$ InformacionGeneral\&pagename $=\mathrm{C}$ eutaTur\%2FPage \%2FInfoSeccionTur\&p pag=InformacionGeneral\&c id=1110294702843. Accessed 26 May 2012.

Cózar, Emilio. 2005. ¿Seguridad ciudadana? (I). El Faro de Ceuta, August 14:3. 
Foucault, Michel. 1985. Discourse and Truth. The Problematization of Parrhesia. Evanston, IL: Northwestern University.

2004. Sécurité, Territoire, Population: Cours au Collège de France 1977-1978. Paris: Seuil/Gallimard.

Ferrer Gallardo, Xavier. 2008. Acrobacia fronterizas en Ceuta y Melilla. Explorando la gestión de los perímetros terrestres de la Unión Europea en el continente africano. Documents d'Anàlisi Geogràfica 51:129-149.

Frederickson, George. 2003. Racism: A Short History. Princeton, NJ: Princeton University Press.

Glick, Thomas F. 1979. Islamic and Christian Spain in the Early Middle Ages. Princeton, NJ: Princeton University Press.

Gold, Peter. 2000. Europe or Africa? A Contemporary Study of the Spanish North African Enclaves of Ceuta and Melilla. Liverpool: Liverpool University Press.

Goldberg, David Theo. 2009. The Threat of Race: Reflections on Racial Neoliberalism. Malden, MA: Blackwell.

González Enriquez, Carmen. 2007. Ceuta and Melilla: Clouds over the African Spanish towns. Muslim minorities, Spaniards' fears and Morocco-Spain mutual dependence. Journal of African Studies 12(2):219-234.

Goode, Joshua. 2009. Impurity of Blood. Defining Race in Spain, 1870-1930. Baton Rouge: Louisiana State University Press.

Haddad, Emma. 2007. Danger happens at the border. Pp. 119-136 in P.K. Rajaram and C. Grundy-Warr, eds., Borderscapes: Hidden Geographies and Politics at Territory's Edge. Minneapolis: University of Minnesota Press.

Hage, Ghassan. 2000. White Nations: Fantasies of White Supremacy in a Multicultural Society. New York: Routledge.

Huysmans, Jeff. 2006. The Politics of Insecurity: Fear, Migration and Asylum in the EU. London: Routledge.

Irujo, José María. 2005. La presión de "nuestro" islam. El País, September $12 . \quad$ www.elpais.com/articulo/espana/presion/islam/ elpepunac/20050912elpepinac 1/Tes. Accessed 5 October 2008.

Kearney, Michael. 1991. Borders and boundaries of state and self at the end of empire. Journal of Historical Sociology 4(1):52-74.

Kernerman, Gerald. 2005. Multicultural Nationalism: Civilizing Difference, Constituting Community. Vancouver: University of British Columbia Press.

López Sala, Ana María. 2012. Donde el sur confluye con el norte: Movimientos migratorios, dinámica económica y seguridad en las relaciones bilaterales entre España y Marruecos. Documentos CIDOB Migraciones 24:1-12.
Malkki, Liisa. 1995. Purity and Exile: Violence, Memory, and National Cosmology among Hutu Refugees in Tanzania. Chicago: University of Chicago Press.

Mariscal, Georges. 1998. The role of Spain in contemporary race theory. Arizona Journal of Hispanic Cultural Studies 2:7-22.

Memmi, Albert. 1985. Portrait du Colonisé, Portrait du Colonisateur. Paris: Gallimard.

Moffette, David. 2010. Convivencia and securitization: Ordering and managing migration in Ceuta (Spain). Journal of Legal Anthropology 2(1):189-211.

Omi, Michael and Howard Winant. 1994. Racial Formation in the United States: From the 1970s to the 1990s. New York: Routledge.

Puar, Jasbir K. 2007. Terrorist Assemblages: Homonationalism in Queer Times London: Duke University Press.

Quesada, Juan Diego. 2010. Contrabando chino en Ceuta. El País, August 29. http://elpais.com/diario/2010/08/29/negocio/1283087004 850215.html. Accessed 26 May 2012

Razack, Sherene. 2008. Casting Out: The Eviction of Muslims from Western Law and Politics. Toronto: University of Toronto Press.

Soifer, Maya. 2009. Beyond convivencia: Critical reflections on the historiography of interfaith relations in Christian Spain. Journal of Medieval Iberian Studies 1(1):19-35.

Torres Colón, Gabriel Alejandro. 2008. Of Muslim Persuasion: The Politics of Convivencia in Ceuta, Spain. Unpublished PhD Dissertation, Department of Anthropology, University of New Mexico.

Vázquez García, Francisco. 2009. La Invención del Racismo: Nacimiento de la Biopolitica en España, 1600-1940. Madrid: Ediciones Akal.

David Moffette is a $\mathrm{PhD}$ candidate in sociology at York University and a Graduate fellow at York Centre for International and Security Studies. His research interests include governmentality studies, immigration policies, law and criminalization, securitization, racism, and eugenics. 
622 (c) Canadian Journal of Sociology/Cahiers Canadiens de sociologie 38(4) 2013 